\title{
4
}

\section{HOW POST-TRUTH POLITICS TRANSFORMED AND SHAPED THE OUTCOME OF THE 2016 BREXIT REFERENDUM}

\author{
Jennifer Cassidy
}

\section{Introduction}

One could affirm that the examination of how post-truth politics transformed and shaped the outcome of the 2016 Brexit referendum would never have gained substantial traction as a research question, were it not for the new communication age we now reside in. Especially during times of heightened divides, be it a domestic election, an international political crisis, or a national referendum, popular online platforms such as Twitter, Facebook, Instagram, etc., are widely used by many politicians and commentators.

The case of the Brexit referendum is very much worthy of examination since, over the past 20 years, the UK has crafted a strong reputation for the quality and standard of its scientific advisory system. This is demonstrated by its array of top-level scientific advisers in almost every department of government and by its willingness to experiment and innovate with new approaches to evidence-based policy-making. But this seemingly progressive arc towards the ever-greater uptake of evidence and expertise in decision-making took a major knock in June 2016 with the result of the referendum on UK membership of the European Union (EU) swinging narrowly, $52 \%$ to $48 \%$, in favour of Brexit. This happened despite a mountain of evidence and the near unanimous support of experts of all kinds for remaining in the EU. The referendum process itself was marred by exaggeration and the use of dubious facts and figures on both sides, but particularly by the Leave campaign, and by accusations of outside interference in the democratic process by a range of murky and unaccountable actors, including the Russian government.

In short, Brexit quickly became one of the 'ideal-type' case studies when it came to discussing, exploring, and examining the role of post-truth politics in the 21 st century. Therefore, the aim and contribution of this chapter to the domains of diplomatic and information studies is three-fold: (1) to expose and confront the 
historical and present nature of 'post-truth' politics; (2) to shed light onto often overlooked tools and mechanisms used in the 21st century playbook of 'post-truth' politics, with a focus on critical junctures of empirical cases such as the 2016 UK Brexit referendum that allows us to reconceptualise post-truth in an age of realtime governance; (3) to suggest that the current political climate of post-truth politics requires the broad promotion of a sort of democratic capability. Drawing on the epistemic aspects of Amartya Sen's work - particularly on his concept of positional objectivity (Sen 1993) - we will discuss and answer the questions, how, why, and should it matter to the challenges faced by our historic, but new, theatre of posttruth politics. This chapter, therefore, aims to offer conceptual and practical tools to help us understand and combat the rise of post-truth politics in the 21 st century.

The overall aim and the interconnected character of these three questions is to examine, expand, and illustrate through empirical moments in the Brexit campaign, that the Leave vote was motivated by post-truth politics. Indeed, not only motivated by it, but actively engaging in its processes, mechanisms, and emotional control of the people it sought to influence. This chapter aims to support these claims by developing an argument about the extent to which the UK's Brexit referendum has been shaped and is continuing to be shaped by post-truth politics. As a starting point for the discussion, the definition of post-truth as a type of "politics which seeks to emit messages into the public domain which will lead to emotionally charged reactions, with the goal of having them spread widely and without concern for the accuracy of the messages provided" will be investigated in detail (Marshall and Drieschova 2018: 89).

\section{Post-truth: Historic concept, new theatre}

We want to find out if post-truth politics is simply a historical concept. Even if history is repeating itself, this does not mean that we have not learned the lessons of the past. It simply means that we have not recognised its patterns when they returned. That is the reason why we study it, analyse it, explore it, dissect it, scrutinise it: so we can recognise it now, as it is today. This new face of 'post-truth politics' is currently akin to a bad artist seeking to help the police by drawing the suspect who has just robbed them. In short, the suspect's features are ill-defined, and it is almost impossible to distinguish most, if any, detail. Yet despite these challenges surrounding clarity, this does not mean the police should stop looking for the suspect in question. As we have already seen with the new techniques and methods of 21 st century post-truth politics, the ones we have seen being actively used by politicians, active governments, and organisations alike come with profuse damage and impact to our national and international governing sphere.

The impact is not simply in the damage done to the elections due to fraud, but due to the polarisation of public discourse, and lies in the inability of many citizens who, bombarded with the terms 'fake news' or 'crisis actors' by governing politics daily, perhaps justifiably simply do not know what to believe anymore. And there is, of course, the issue of credibility. Despite the fact that the term 'post-truth 
politics' is nothing new, as academics we need to reconceptualise and contextualise it. That is, we need to analyse, individually and comparatively, all new methods, tools, technologies that are challenging, impacting on, and shaping our international political system.

\section{Background to the 2016 Brexit referendum}

The UK's referendum on the EU membership, now infamously known as Brexit, took place on 23 June 2016 in the United Kingdom and Gibraltar. The purpose of the vote was to gauge support for the country either remaining a member of, or leaving, the EU. Campaigning began immediately after the referendum's calling. This is a very important thing to note, and indeed a strong variable of why the referendum, its outcome, and continued controversy remain today. Just like the historical roots of post-truth, the tensions connected to the Leave-Remain confrontation within the society and Parliament itself, were and are nothing new. These tensions have presented themselves in many forms since the UK's official entry into the Union in 1973. Yet now the vote had been called. Divides established. With allegiances by politicians and citizens alike, largely known to all.

The underpinnings of controversy, discontentment, and attachment with the UK's continued relationship with Europe are clearly illustrated by a number of instructive examples. First, in 2013 Prime Minister David Cameron stated clearly in a long-awaited speech that if the Conservatives won the next election they would seek to renegotiate the UK's relationship with the EU. Then, by the end of 2017 they would give the British people the "simple choice" between staying in the EU under those terms or leaving the EU. It would be a few years before the election was called, but the seeds of division had certainly not only been sown, but watered. Second, was the creation and emergence of clearly divisive institutions. One such example was the creation of a cross-party, formal group campaigning for Britain to Remain a member, called 'Britain Stronger in Europe'. It was established in October 2015, directly after 'The European Union Referendum Bill' was unveiled in the Queen's Speech. ${ }^{1}$ Alongside this, there was the creation of two groups promoting exit which sought to be the official Leave campaign: Leave.EU (supported by most of the UKIP party, led by Nigel Farage), and Vote Leave (supported by Conservative party Eurosceptics). The Electoral Commission announced on 13 April 2016 that Vote Leave was the official Leave campaign. The UK government's official position was to support the remain option. Before we examine, dissect, and explore the tactics, methods, and challenges faced in a posttruth world in an age of real-time governance, we will conclude by stating what many of us now know to be objective truth. On 23 June 2016, the people of the United Kingdom and Gibraltar were asked: "Should the United Kingdom remain a member of the European Union or leave the European Union?" There were two boxes to answer this complex question: 1) Remain a member of the EU; 2) Leave the EU. The referendum turnout was $71.8 \%$, with more than 30 million people voting. Leave won by $51.9 \%$, while Remain got $48.1 \%$ of the votes. 
It should be noted that the Brexit campaign was distinct from other referendums or elections because of the unexpectedly high turnout from voters who do not normally vote in British general elections. The voter turnout for the referendum was $72.2 \%$. This is in comparison to a $68.8 \%$ turnout in the 2017 General Election, a $66.2 \%$ turnout in $2015,65.1 \%$ in $2010,61.4 \%$ in 2005 , and $59.4 \%$ in 2001. The referendum was the first major UK vote since 1997 to go above a $70 \%$ turnout (Electoral Commission 2017). From YouGov polls, to newspapers, all predicted a Remain vote. The higher turnout, particularly in the north of England, contributed to the miscalculation of the result (YouGov 2016a). People who did not normally vote decided to vote in the EU referendum, and they voted leave. This raises the question of what motivated the high turnout and what led the 1.2 million previously disengaged voters to find the leave message more convincing.

As noted by Moore and Ramsay (2017: 168), the Brexit campaign was "divisive, antagonistic and hyper-partisan (. . .)", as its continued divisive nature and polarising rhetoric, which characterised both sides, has shown before, during and after the vote. To quote Hannah Marshall and Alena Drieschova (2018: 94), "Both 'sides' actively accused each other of dishonesty and scaremongering, and these discursive tactics did little to inspire trust from the public in the debate as a whole. Rather, the public were encouraged to distrust political messaging based on constant back and forth accusations and disparagement." And yet, the two key messages the public remembered from the referendum campaign - that we will directly discuss and examine throughout this chapter - were components of key arguments belonging to Brexiters.

1. "The UK sends $\$ 350 \mathrm{~m}$ per week to the EU"

2. "Net migration to the UK had hit 333,000"

These key themes of focus during the referendum became rapidly and increasingly significant in the national press (Joyce 2017). The narrative of the Vote Leave campaign, a narrative based on these two core themes, gained traction, and not simply gained traction, but embedded itself in the hearts and minds of the public in a way the Vote Remain campaign did not. What the referendum therefore clearly demonstrated was that two single pieces of pro-Leave campaign material - (1) a slogan on the side of a bus fallaciously implying that leaving the EU would necessarily free up $_{350}$ million a week for the NHS; and (2) a poster stating that Britain was at its "Breaking Point" purportedly due to an influx of migrants - proved highly controversial but successful in winning the hearts and minds of the British public.

It is worth noting, particularly in a chapter dedicated to post-truth politics, that these themes, slogans, arenas of deception that won the heart of many voters were at best misleading, and at worst outright false. For example, the Leave side's widely publicised claim that

[t]he UK sends $f^{350}$ million per week to the EU is wrong. [ . . ]. This figure does not include the rebate, or discount on what the UK has to pay. 
In 2014 , the UK would have paid $£ 18.8$ billion without the rebate but ended up paying f 14.4 billion. The estimate for 2015 is $f 12.9$ billion. This is £248 million per week, or £35 million per day

(FullFact 2016b).

Yet, in an opinion poll conducted by "Whatukthinks" (2016c), asking the question "Is It True or False That Britain Sends _350 Million a Week to the European Union?", 47\% of respondents thought the former message was accurate (Whatukthinks 2016c). These examples point once again directly to the central thesis at play here: the influence that post-truth politics had on the UK's Brexit 2016 referendum. In the next section, we will examine these cases and sketch the 'key posttruth moment' which ultimately and arguably shaped the voting outcome, not to say the future of Ireland and the resources and agenda setting power of the EU for the next three years.

\section{The NHS bus poster}

The now-infamous NHS bus was deployed by Vote Leave, the official campaign group for Brexit as designated by the Electoral Commission. It stated: "We send the EU $\mathcal{E}_{350}$ million a week, let's fund our NHS instead". In defence of this propagandistic slogan, or at best highly misleading statement, many Leave campaigners have argued that they simply used the figure of "the cost of an NHS hospital". The Leave campaigners justified their claims further, stating that the stark slogan was necessary in order to illustrate how expensive remaining in the EU was. Conversely, those standing firmly on the side of Remain, presented the argument that by using this slogan, the Leave side was presenting misleading and false information. Not only did they contend that such an act was morally objectionable, but that the consequence of this act would be momentous for the whole campaign. Their fears proved to be well-founded. The slogan sought to have appeared to

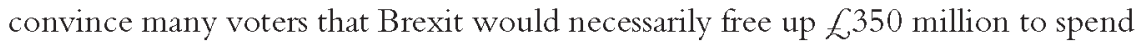
on the NHS. Leave campaigners have consistently backed away from this claim since the vote (Griffin 2016).

Indeed, there have been some preliminary challenges to the use of the image. For example, the Advertising Standards Agency received 374 complaints. $^{2}$ A group called Vote Leave Watch was formed with the single aim of holding the government and groups like Vote Leave accountable. They also sought to force the government, and as many Leave voters as possible, to admit that the bus was misleading. The group regularly brought up suggestions that the referendum ought to be repeated because of the dishonesty of the Leave side, and the belief that "the leave side won because they ... promised something that does not exist" (Rothstein 2016).

It is true that calculating the cost of EU membership for any country, let alone the UK, is a complicated task; however, the claim showed on the bus was inaccurate by any reasonable measure. A naive defence of the Leave campaign emerged 
that because the figure was hard to reach, thus they went for the best possible figure for their cause. To quote Andrew Reid (2019) on this very point, he writes "A cynic would see it as a lie designed to convince voters of a simple untruth." Such an interpretation would "seem inadequate, especially given that the statements of key Leavers and commentators on the campaign suggest more subtle and nuanced motivations." Dominic Cummings, the political operative who acted as the campaign chief for Vote Leave, also noted in a personal blog that: "Pundits and MPs kept saying 'why isn't Leave arguing about the economy and living standards'. They did not realise that for millions of people, $f 350 \mathrm{~m} / \mathrm{NHS}$ was about the economy and living standards ... It was clearly the most effective argument . . with almost every demographic" (Cummings 2017).

It should be noted that Cummings' journal entry was not intended as a tool for convincing the people of his commitment to his 'truth'. Instead, he denoted in tone and contested ideas to the aged-old act of telling "compelling stories"; in this case, connecting the EU to a general dissatisfaction with the economic state of the country (ibid.). The idea behind the slogan on the bus was arguably on reflection, to exploit a widespread prejudicial belief about the costs of EU membership, deviating the public's attention from considering its benefits. As Shipman puts it in his account of the campaign, "[e]very time there was a row about the size of the cost to taxpayers of EU membership, it simply reinforced in voters' minds that there was a high cost" (2017: 259). As Reid (2019) writes so clearly: "The idea here was that as soon as any Remainer responded to the NHS bus with a response of the kind: 'actually, EU membership costs $\mathrm{XX}_{\mathrm{X}}$ million instead', they were already on the back foot because they were talking about costs not benefits." Indeed, in a post-truth environment, none of these asserted points depended upon people being convinced of the specifics of the claim. Despite this, acts of this nature, falsehoods (whether contested or not) spread like wildfire through a nation, and are proved to have damaging effects on democratic discourse by 'muddying the waters' in factual deliberations.

The key axes in the 2016 Brexit referendum can therefore be thought of as an example of what Yale philosopher Jason Stanley calls "undermining propaganda". This refers explicitly to acts of speech that involve "erecting difficult epistemic obstacles to recognising tendencies of goals to misalign with certain ideals" (2015: 57). The idea itself of "undermining propaganda" is applied broadly to the study and analysis of Stanley's work, referring in many instances to the deeper ideological or moral commitments that underpin society. We can arguably draw on its conceptual underpinnings to examine the factual deliberations in this case. The key phrase in Stanley's definition is "epistemic obstacle". We can link this clearly to the NHS bus being introduced as such an obstacle, due to resulting consequences for members of the public to establish what the costs and benefits of Brexit truly were. The act of the slogan, and the creators behind it, did this by wrongly problematising the epistemic authority of some bodies and figures, and as a practical consequence eroded the set of common factual reference points in what should have been a fair, free, and open debate. 
The words of Andrew Reid (2019) on his work on Brexit and disinformation conclude it best when he writes:

The troublesome function of the NHS bus, then, is to neutralise the discussion of the economic impact of Brexit by increasing scepticism of all factual claims, and presenting all predictions as equally bad. It nullifies the issue by reducing the set of commonly accepted, relevant facts and therefore making it harder to come to judgments about the effects of different policy option.

\section{The Breaking Point}

The Vote Leave campaign was led by individuals like Boris Johnson, who created a narrative, or historic reflection, of re-establishing Britain as a global hegemon. Indeed, many of the key leaders of the Vote Leave campaign articulated a narrative of British nationalism that was more insular and Powellite in tone. At the centre of this perspective lay the concerns and increasingly stirred fears surrounding immigration. According to Nigel Farage, the figurehead of Leave.EU, the EU had done insurmountable harm to Britain by facilitating uncontrolled immigration: "Opendoor migration has suppressed wages in the unskilled labour market, meant that living standards have failed and that life has become a lot tougher for so many in our country" (Farage 2016).

This actively and carefully constructed narrative creation played on people's fears, whilst weaving perfectly into the nationalistic tone of 'Britain First' that the Leave leaders were exalting across the country. Comparatively, this is not too dissimilar from what is occurring across the water, where we see slogans of 'Make America Great Again' capture voters in their droves, changing the landscape of the 'shining city on the hill' forever. Furthermore, according to what Virdee and McGeever (2018: 1806) argued in their article entitled 'Racism, Crisis, Brexit': "the construction of the migrant as economic threat to the domestic working class was married to a second set of representations that understood the migrant as security threat to the British population." The authors conceptualise this process of misrepresentation into three distinct elements. First, the terrorist attacks in France and Belgium and the onset of the migration to Europe of displaced Syrians and others escaping war in 2015 and 2016 were purposely linked by Farage to make the argument that the "EU's open borders make us less safe" (Farage 2016). This created a gateway for him to imply that by getting "our borders back, our democracy back" through exiting the EU we could also restrict the entry of such "undesirables" and make Britain safe again. According to Virdee and McGeever, the second element integral to this construction of migrant as security threat was that leaving the EU would effectively prevent refugees from seeking sanctuary in Britain, since it would no longer be party to the EU's central benefit freedom of movement between EU member countries. This argument reached its zenith with the creation and posting of the Leave.EU's "Breaking Point" poster. A poster showing Middle Eastern refugees queuing at Europe's borders. The subheading 
read: "We must break free of the EU and take back control." This was a message of 'island retreat' (Winter 2016): if Britons voted Leave, they could successfully keep such people from entering the country. Finally, the third component conceptualised by Virdee and McGeever on the nature of post-truth narratives of racism, was highlighted when recently arrived migrants were alleged to have committed a series of sexual assaults in Germany - the EU country which had accepted almost a million refugees in 2015. Leave.EU "campaigners contributed to a moral panic that understood refugees as 'sexual predators', reinforcing the message that remaining in the EU would place British women at risk" (Virdee and McGeever 2018).

While the Breaking Point poster, and the integrated narratives and acts surrounding it, may lie at the margins of hateful speech, they have not been subject to criminal sanction. However, according to Reid (2019), although it may not be regarded as hate speech, he justifiably writes:

[Such acts do] transgress the norms expected of political campaigns because of [their] potential effect on political voice, so should be subject to limited sanctions within this sphere. Such hate speech can, when practiced by political elites, have harmful effects on the democratic forum, and as such might be subject to measures that amount to partial censorship when practised by political parties or recognised campaign groups.

Indeed, although recent migrants would not have been able to vote in the referendum, it remains evident that their voice is valuable and warranted on this subject matter. Thus, the persistent use of nationalistic and discriminatory imagery like that of the Breaking Point poster by those in positions of relative authority can, and do, invariably cause a shift in public perceptions that leads to certain target groups being silenced, their voices not being heard, or when they do choose to speak up, the consequence is that they are not taken seriously in political deliberation. This amounts to what is deemed a de facto exclusion from the process of deliberating over laws due to the loss of an effective political voice.

These consequences have been discussed in other works on hate speech, for example when Jeremy Waldron, in a very influential essay on the issue, discusses "group defamation" or "group libel" (2012: 39-40). This is the spreading of mistruths about groups within society that causes them to be treated unfairly or unjustly. Waldron also emphasises the loss of dignity that occurs when we are frequently part of a "disfiguring social environment" where such ideas persist (ibid.: 117). The "disfiguring social environment" I am concerned with is one that contributes to a situation where some are treated as inferiors in political deliberation: this undermines their effective political voice, because it causes others to treat them differently. The loss of esteem in the eyes of other citizens can lead to members of groups targeted by hate speech suffering epistemic injustices (Fricker 2007). One manifestation of epistemic injustice is "testimonial injustice", the injustice of being doubted as a knower, or of having the integrity of one's knowledge challenged (ibid.: 1-2). Minority groups can therefore be forced to deliberate as if such 
stereotypes are true in order to facilitate a productive dialogue; Stanley uses the example of African Americans who end up participating in debates where racist stereotypes that they are lazy or violent persist (2015: 163). This analysis can be applied to the Breaking Point poster, which depicts non-white citizens and recent migrants as a hostile force, and a drain on the national community's resources. Deliberating when these traits are assumed at the outset means accepting disrespectful falsehoods, and a concurrent loss of perceived credibility. It is to deliberate at a disadvantage, as it requires the internalisation of a norm that the speaker is less trustworthy or able. Such is the world of post-truth politics in the 21 st century.

\section{Conclusion}

By referring to Brexit as an 'ideal-type' case study for understanding the mechanisms and the effects of post-truth politics, the chapter has shown how the Vote Leave campaign around the referendum was built on misleading narratives that touched very sensitive topics such as the NHS and immigration control. Though neither of the two topics are directly related to EU membership, some of their aspects were exaggerated and framed as though they were part of the overall discourse on permanence in the EU.

The referendum was a quite divisive political instrument per se, and by appealing directly to the people it favoured the diffusion of manipulated narratives for pure electoral ends, neglecting the overall good of the country. The themes, slogans, and arenas of deception that won the heart of many voters were misleading at best, and outright false at worst. Furthermore, both factions actively accused each other of dishonesty and scaremongering, nourishing confusion and distrust among the electorate. And yet, the two key messages the public remembered from the referendum campaign were components of key arguments belonging to Brexiters: a slogan on the side of a bus that fallaciously implied that leaving the EU would as a direct consequence free up money for the NHS, and a poster stating that Britain was at a "Breaking Point" because of an immigration crisis. The path to the Brexit referendum was thus riddled with difficult epistemic obstacles that kept the people from understanding the real implications of their choice.

\section{Notes}

1 Before the vote had cleared Parliament and become law, the serving government twice saw off attempts in the House of Lords to lower the proposed voting age in the in-out poll to 16. Their attempts, as history has shown us, proved unsuccessful.

2 See Parker (2016) for a journalistic discussion of this issue.

\section{References}

Arendt, H. (1973) The Origins of Totalitarianism, New York: Harcourt Brace Jovanovich. Crilley, R. (2018) 'Book review essay: International relations in the age of "post-truth" politics', International Affairs 94(2): 417-25. 
Cummings, D. (2016) 'On the referendum \#2.0: The campaign, physics and data science Vote Leave's "Voter Intention Collection System" (VICS) now available for all', https:// dominiccummings.com/2016/10/29/on-the-referendum-20-the-campaign-physicsand-data-science-voteleaves-voter-intention-collection-system-vics-now-available-forall/ (last consulted 5 May 2020).

DeCesare, A. (2018) 'Working toward transpositional objectivity: The promotion of democratic capability for an age of post-truth politics', The Good Society 26(2-3): 218-33.

The Economist (2016) 'Art of the lie', 10 September 2016, www.economist.com/leaders/ 2016/09/10/art-of-the-lie (last consulted 5 May 2020).

Electoral Commission (2017) 'The 2016 EU referendum: Report on the regulation of campaigners at the referendum on the UK's membership of the European Union held on 23 June 2016', www.electoralcommission.org.uk.

European Commission (2018) 'Tackling online disinformation: Commission proposes an EU-wide code of practice', http://europa.eu/rapid/press-release_IP-1 8-337 0 _en.htm (last consulted 5 May 2020).

Farage, N. (2016) 'NIGEL FARAGE: Why we must vote LEAVE in the EU referendum', Express, 21 June 2016, www.express.co.uk/comment/expresscomment/681776/ nigel-farage-eu-referendum-brexit-vote-leave-independence-ukip.

Fricker, M. (2007) Epistemic Injustice: Power and the Ethics of Knowing, Oxford: Oxford University Press.

FullFact (2016a) 'False claims, forecasts, and the EU referendum', https://fullfact.org/ europe/false-claims-forecasts-eu-referendum/ (last consulted 5 May 2020).

FullFact (2016b) 'Vote leave "facts" leaflet: Membership fee', https://fullfact.org/europe/ vote-leave-facts-leaflet-membership-fee/ (last consulted 5 May 2020).

Griffin, A. (2016) 'Brexit: Vote leave wipes NHS f350 claim ...', The Independent, 27 June 2016, www.independent.co.uk/news/uk/home-news/brexit-vote-leave-wipes-nhs350m-claim-and-rest-of-its-website-after-eu-referendum-a 7105546.html (last consulted 5 May 2020).

Joyce, B. (2017) 'Brexit data: Post-truth politics and the EU referendum', Brandwatch, www. brandwatch.com/blog/react-brexit-post-truth/.

Marshall, H., A. Drieschova (2018) 'Post-truth politics in the UK's Brexit referendum', New Perspectives Interdisciplinary Joumal of Central \& East European Politics and International Relations 26(3).

Moore, M., G. Ramsay (2017) 'UK media coverage of the 2016 EU referendum campaign', Centre for the Study of Media, Communication and Power.

Parker, G. (2016) 'The ASA can't regulate political advertisements. Here's why', The Guardian, 6 July 2016, www.theguardian.com/commentisfree/2016/jul/06/advertising-standardsauthority-political-advertisements (last consulted 5 May 2020).

Reid, A. (2019) 'Buses and breaking point: Freedom of expression and the "Brexit" campaign', Ethical Theory and Moral Practice 22: 623-37.

Rothstein, B. (2016) 'It's perfectly sensible to want a second referendum. Here's why', New Statesman, 7 September 2016, www.newstatesman.com/politics/staggers/2016/09/ its-perfectly-sensible-want-second-eu-referendum-heres-why.

Sen, A. (1993) 'Positional objectivity, Philosophy \& Public Affairs 22(2): 126-45.

Shipman, T. (2017) All Out War: The Full Story of Brexit (revised edition), London: William Collins.

Stanley, J. (2015) How Propaganda Works, Princeton: Princeton University Press.

Virdee, S., B. McGeever (2018) 'Racism, crisis, Brexit', Ethnic and Racial Studies 41(10): 1802-19.

Waldron, J. (2012) The Harm in Hate Speech, London: Harvard University Press. 
whatukthinks (2016a) 'Are politicians from both the Leave and Remain campaign mostly telling truth or lies?', https://whatukthinks.org/eu/questions/8070/ (last consulted 5 May 2020).

whatukthinks (2016b) 'How likely or unlikely do you think it is that Turkey will join the EU in the next 10 years?', https://whatukthinks.org/eu/questions/how-likely-orunlikely-do-you-think-it-isthat-turkey-will-join-the-eu-in-the-next-10-years/ (last consulted 5 May 2020).

whatukthinks (2016c) 'Is it true or false that Britain sends $f 350$ Million a week to the European Union?', https://whatukthinks.org/eu/questions/is-it-true-or-false-that-britainsends-350-million-a-week-to-the-european-union/ (last consulted 5 May 2020).

whatukthinks (2016d) "To what extent is the way you intend to vote in the EU Referendum based on your heart or your head?', https://whatukthinks.org/eu/questions/ to-what-extent-is-the-way-youintend-to-vote-in-the-eu-referendum-based-on-yourheart-or-your-head/ (last consulted 5 May 2020).

whatukthinks (2016e) 'Whose opinions have influenced your decision on how to vote in the referendum?', https://whatukthinks.org/eu/questions/whose-opinions-have-influencedyourdecision-on-how-to-vote-in-the-referendum/ (last consulted 5 May 2020).

Winter, A. (2016) 'Island retreat: On hate, violence and the murder of Jo Cox', Open Democracy, 20 June 2016, www.opendemocracy.net/uk/aaron-winter/island-retreat-on-hateviolence-and-murder-of-jo-cox.

Wise, D. (1973) The Politics of Lying, New York: Random House.

YouGov (2016a) 'Unexpectedly high turnout in Leave areas pushed the campaign to victory', 24 June 2016, https://yougov.co.uk/news/2016/06/24 /brexit-follows-closerun-campaign/ (last consulted 5 May 2020).

YouGov (2016b) 'YouGov on the day poll: Remain 52\%, Leave 48\%', 23 June 2016, https:// yougov.co.uk/news/2016/06/23/yougov-day-poll/ (last consulted 5 May 2020).

Younge, Gary (2016) 'Brexit: A disaster decade in the making', The Guardian, 30 June 2016, www.theguardian.com/politics/2016/jun/30/brexit-disaster-decades-in-the-making (last consulted 5 May 2020). 